\title{
Review
}

\section{Hope in a secular age: Deconstruction, negative theology, and the future of faith}

\author{
David Newheiser \\ Cambridge University Press, Cambridge, 2019, vii+177 pp., \\ ISBN: 9781108498661
}

Contemporary Political Theory (2022) 21, S165-S169. https://doi.org/10.1057/s41296021-00523-8; published online 15 September 2021

Scholarship on the nature and role of negativity in philosophy and political theory has surged the last twenty years. From Diana Coole's Negativity and Politics (2000) to Benjamin Noys' The Persistence of the Negative (2010), the politically productive nature of the negative, either as a tool of sociopolitical critique or an instrument of repoliticisation, has come to the fore for good or ill. Sympathisers usually extol the power of the negative to break the crust of dominant ideologies and sedimented practices, while detractors tend to point to the politically debilitating nature of endless critique. Siding with the former, David Newheiser's new book investigates the workings of negativity from the viewpoint of political theology. His study explores the ethical and political potency of what he calls 'negative political theology' as an ethical practice of religious and secular hope. To show how this is possible on both registers, religious and secular, the book examines together a twentieth-century atheist philosopher, the father of deconstruction Jacques Derrida, and a sixth century Christian Neoplatonist monk, (Pseudo-)Dionysius the Areopagite, known for recommending a theology of 'unsaying' (in Greek, apophasis) that relativised both negative and affirmative statements about God. For Newheiser, such an apophatic political theology sustains 'a discipline of hope' (p. 7), as he terms it, a form of ethical practice that seeks to affirm sociopolitical projects without assurances and engage in self-critique without undermining the possibility of affirmative political action.

Newheiser believes that genuine hope can be sustained by both secular and religious resources, provided that hope is understood, not as nebulous optimism about the future nor as the promise of otherworldly compensation for a life lived in misery and suffering, but as 'a disciplined resilience that enables desire to endure without denying its vulnerability' (p. 2). To show how this is possible in secular discourse, Newheiser sets out first to defend the ethico-political significance of Derrida's deconstructive project against its critics, who see in it a nihilistic instrument of endless critique or a politically debilitating negativity. Newheiser

(C) 2021 The Author(s), under exclusive licence to Springer Nature Limited. 1470-8914 Contemporary Political Theory Vol. 21, S4, S165-S169

www.palgrave.com/journals 
convincingly reconstructs what is by now common knowledge to careful readers of Derrida, namely that Derrida's thought explores the possibility of an affirmation that resists complacency and dogmatism. This is best exemplified in Derrida's ethics of uncertainty as articulated in his later work but already prefigured in his early writings. The latter, for Newheiser, constitute an exercise in the discipline of hope. Against those who read Derrida's political ethics as an invitation to inaction and moral relativism, Newheiser argues that Derrida insists on the necessity of judgement in circumstances that remain incalculable. The Derridean aporia then is not simply a symptom of irresolvable contradictions but becomes generative of ethical possibilities that encourage 'experimental affirmation' (p. 30). Through a close reading of a variety of Derrida's early and late texts, Newheiser reminds us that Derrida navigates a path between affirmation and critique by relying on a Kafkaesque/Benjaminian idea of 'hope against hope that is directed towards the unforeseeable' (p. 39), or else an ascesis of hope whose pursuit is as elusive as it is necessary.

Having established the potential for a politically effective hope in secular discourse, Newheiser then turns to the tradition of Christian negative theology and, more specifically, to the apophatic language of Dionysius the Areopagite. For Newheiser, Dionysian apophasis represents a type of religious hope that keeps the knowing and unknowing of God in unresolved tension. Dionysian negativity does not privilege the divine 'darkness of unknowing' (p. 54) over the naming of God. Rather, it exposes the inadequacy of both or, better, the incapacity of language to exhaust the truth of the divine. Newheiser emphasises that apophasis does not imply negation but inexhaustibility. Given this, Dionysian apophatic theology is not an epistemological organon but an ethical discipline oriented towards 'ethical transformation' (p. 48), an experience of the divine that presupposes the dispossession of the self from all idolatrous commitments, even those dictated by sacrality. That said, Newheiser defends Dionysian negative theology against charges that reduce all sacral language to a veiling operation. The task is not easy, as Dionysius seems to engage in the construction of an intricate cosmic hierarchy and the affirmation of a robust sacramental ontology that sustain Christian worship, however radically he strives to relativise those commitments. What for secular thinkers appears as plain contradiction or dogmatic idolatry (by naming the nameless) in the service of Christian theism, for Newheiser it reveals the eschatological dimension of Dionysian mysticism. The sacraments do not veil but, as the signs that they are, point to something beyond themselves, divine inexhaustibility, as part of a communal practice whose truth points to an excess of meaning. By simultaneously defending and unravelling both divine timelessness and time-boundedness, its visibility and invisibility, Dionysian apophasis disrupts the theism/atheism dichotomy and raises faith to an ethical exercise in uncertainty.

In the next two chapters, Newheiser clarifies the nature of hope that the previously analysed perspectives, deconstruction and negative theology, authorise, 
while also provocatively arguing that that they may not be identical in content but they are in kind. Against Camus, for whom hope is an escape from the absurd, both Derrida and Dionysius are shown to affirm a vision of hope that resists despair and persists in the face of uncertainty. Yet Newheiser suggests that Dionysian eschatology sustains a practice of Christian hope that paradoxically is not very different from Camus' pessimism, sharing with it a disposition that refuses to resurrect phantoms of certainty as a defence mechanism against the emptiness of existence. Human arrogance collapses before the unpredictability and incomprehensibility of Christ' (p. 70) that shatters any confidence in all things given or grasped. Similarly, Derrida's hope is a messianic wager to an open future that is constantly to come, a hope that, like Dionysus', can 'endure darkness' (p. 74) without despair or false optimism. For both thinkers, hope is a self-critical discipline that upholds practical endeavours, especially amidst the ineradicable fragility and vulnerability of human life, resisting both indeterminacy and dogmatic complacency. There are parts in the analysis where one may go away with the slightly exaggerated impression that Dionysius is Derrida avant la lettre and Derrida a twentieth-century reincarnation of the Greek-Syrian monk. Still Newheiser is particularly convincing in documenting Derrida's complex understanding of negative theology and the elective affinities of Derridean concepts, such as differance and khôra, with the Dionysian term hyperousios (a state of being beyond substance). The latter, rather than foregrounding religious mysticism as secrecy by referring to an unknown divine substance, signifies a modality of negativity as excessiveness. Such an apophatic disposition rejects both endless indeterminacy and static affirmation for a negativity that can be 'politically potent' (p. 105).

In the last two chapters, Newheiser attempts to make good on that latter claim, namely the political significance of apophatic hope, by exploring the points of convergence between religion and secular politics and defending a negative political theology that neutralises the idolatrous functions of the sacred without disavowing it altogether. The old argument for the separation of religion and politics is found wanting on grounds that are by now well established in the works of Charles Taylor, Talal Asad, Jose Casanova and William Cavanaugh. Building on their insights, Newheiser shows not only that the myth of the symbiosis between violence and religion is unfounded but also that many of the sacred achievements of modern humanism cannot really be separated from their Christian heritage. What is more, Newheiser recovers some of the lesser known works of Derrida in order to claim that the French philosopher should be counted among those who were very much aware of the Christian origins of the phenomenon of secularisation. Religion in such a context becomes a discourse of uncertainty and alterity where negative theology and radical atheism blend into each other to the consternation of avowed atheists like Martin Hägglund. If Derrida's work guards against polemical atheism becoming a reversed dogmatism, Dionysian apophaticism rescues religion from

(C) 2021 The Author(s), under exclusive licence to Springer Nature Limited. 1470-8914 Contemporary $\quad$ S167 Political Theory Vol. 21, S4, S165-S169 
serving an idea of the sacred that legitimates authority. In combating Giorgio Agamben's blanket critique of religious mysticism and glorification, Newheiser advocates a negative political theology that resists the temptations either of revolutionary anarchism or of the unreflective glorification of power. Instead, his is a vision of democratic politics that finds in apophatic hope a democratic tool of self-critique without denouncing ambiguity and the necessity of compromise in actual politics.

Perhaps due to Newheiser's pragmatic leanings, a prominent zealot of negative political theology who receives no mention in the book is Jacob Taubes. The doyen of Jewish negative political theology and revolutionary anarchism would represent perhaps exactly the opposite of what Newheiser has in mind in his defence of a discipline of hope that counters both nihilistic destruction and a politics of dogmatic conviction. However, it is odd that in a book about negative political theology Taubes' (2004, p. 103) apocalyptic nihilism which insisted on 'no spiritual investment in the world as it is', as he put it, is not even discussed or refuted. If nothing else, such a refutation would have provided additional clarity to Newheiser's differentiation from the Gnostic or otherworldly connotations that Taubes' negative political theology is usually associated with.

That said, the book is excellent in substantiating the common debt that certain types of secular and religious ethics owe to religious apophaticism. Indeed, reacquainting oneself with the complex genealogy of apophatic theology, rather than its misreading which one often encounters, reveals a shared religious and secular concern for the exploration of, what from Nietzsche onwards has been called the conditions of affirmative nihilism in modernity, consisting in the nullification of those elements that hold life captive without denying life itself. In that context, what might have forced Newheiser to rethink his romance with Derrida would be to consider whether secular nihilism is as radical as Dionysian apophaticism. One wonders whether Derrida's formalistic messianism does not still retain an air of inexorability (as necessarily endless deferral) that Dionysian surrender to something that has already superseded it manages to avoid (thus sustaining a less self-assured hope and a more affirmative relation of hope to life). Even more so, if such a radical abandonment to another life (where justice, emancipation, democracy is a way of life) is only retrievable from within a practice of faith that challenges the politics of this world (as the politics of strategic calculation, prudence, and compromise), one fears that Newheiser has perhaps brought negative theology too close to a paradigm of worldly politics, of which the latter stands in judgement. I would agree that Taubes may have gone too far in his purist denunciation of the 'world as it is', but some of his prophetic and seditious spirit can still serve as a corrective to tendencies that may unwantedly diffuse the self-abnegating, politically radical, and life-transformative nature of apophaticism. 


\section{References}

Coole, D. (2000) Negativity and Politics: Dionysus and Dialectics from Kant to Poststructuralism. London: Routledge.

Noys, B. (2010) The Persistence of the Negative: A Critique of Contemporary Continental Theory. Edinburgh: Edinburgh University Press.

Taubes, J. (2004) The Political Theology of Paul. Stanford: Stanford University Press.

Publisher's Note Springer Nature remains neutral with regard to jurisdictional claims in published maps and institutional affiliations.

Vassilios Paipais

University of St Andrews, St Andrews, Scotland KY16 9AX, UK vp31@st-andrews.ac.uk 